\title{
Søpindsvin og danekrce - flotte fund fra hele landet
}

Af geologisk konservator Søren Bo Andersen Geologisk Institut, Aarhus Universitet med bidrag af Jytte Frederiksen, Jysk Stenklub

Langt de fleste danskere kender ordet søpindsvin og måske især som "forstenet søpindsvin" - det er jo disse meget specielle flintesten med fine prikker og linier, som man finder ved stranden, eller hvor der ellers er mange sten til stede her i Danmark.

\section{Hvad er søpindsvin?}

Men er måske så også alle klar over, at disse "forstenede søpindsvin" er flint udfældet inden i de skaller, som engang husede og var et levende dyr for mere end 60 millioner år siden? Den almindeligste type "forstenede søpindsvin”, som man finder i Danmark, er udfyldninger af flere arter af slægten Echinocorys. Søpindsvin lever i høj grad også i nutiden. Den gamle slægt Echinocorys lever ikke længere, der er kommet andre former til, men visse af nutidens søpindsvin har letgenkendelige slægtninge, som man kan finde i de danske kalklag fra Sen Kridt og Danien (alder: ca. 70-62 millioner år) og også som udfyldninger af flint. Søpindsvin er bundlevende havdyr. De har en skal af kalkplader, og på ydersiden bærer de en mængde pigge.

Søpindsvinene kan opdeles i to hoved-

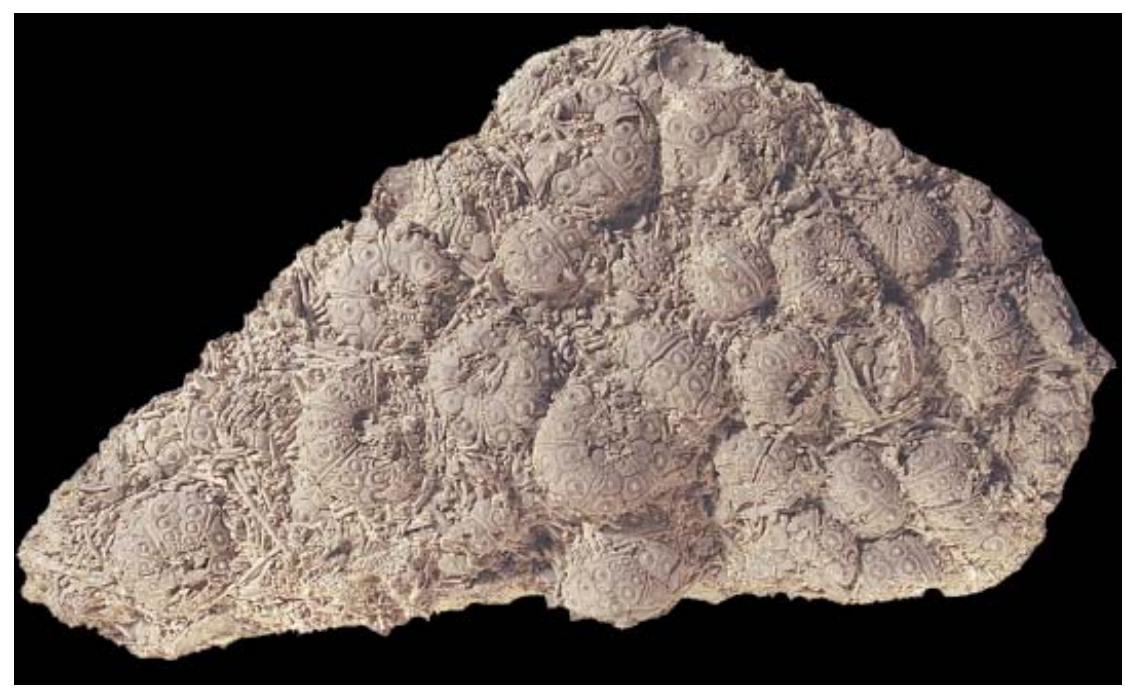

DK 3. Temnocidaris danica. 25 skaller med pigge og tandapparater. Kalksten, Mellem Danien, Fakse Kalkbrud. (Foto: Sten L. Jakobsen, Geologisk Museum, Kbh.)

grupper, de regulære og de irregulære. De regulære er den geologisk set ældste gruppe, hvorfra de irregulære senere er udviklet. De regulære lever oven på havbunden, de har kraftige, ofte meget lange, pigge, og de lever ved at afgnave alger og andet med deres specielle kæbe-/tandapparat. De irregulære søpindsvin, derimod, har meget korte og fine, næsten børsteformede, pigge, hvilket passer med deres levevis som enten delvis eller helt nedgravet i løs havbund. De fleste irregulære har ikke tandapparat, men "plukker” fødepartikler med særlige sugefødder i nærheden af munden. Alle søpindsvin har sugefødder til bevægelse og iltoptagelse, og som fra det indre gennemtrænger dyrets skal i fem dobbeltrækker. Det er aftryk af hullerne efter disse sugefødder, der viser sig som rækker af prikker på de forstenede søpindsvin.

\section{Hvad er danekræ}

Danekræ er en betegnelse for særligt interessante eller værdifulde fund af bl.a. fossiler (forsteninger). Der gælder i Danmark en lov, der trådte i kraft 1 . januar 1990, som 


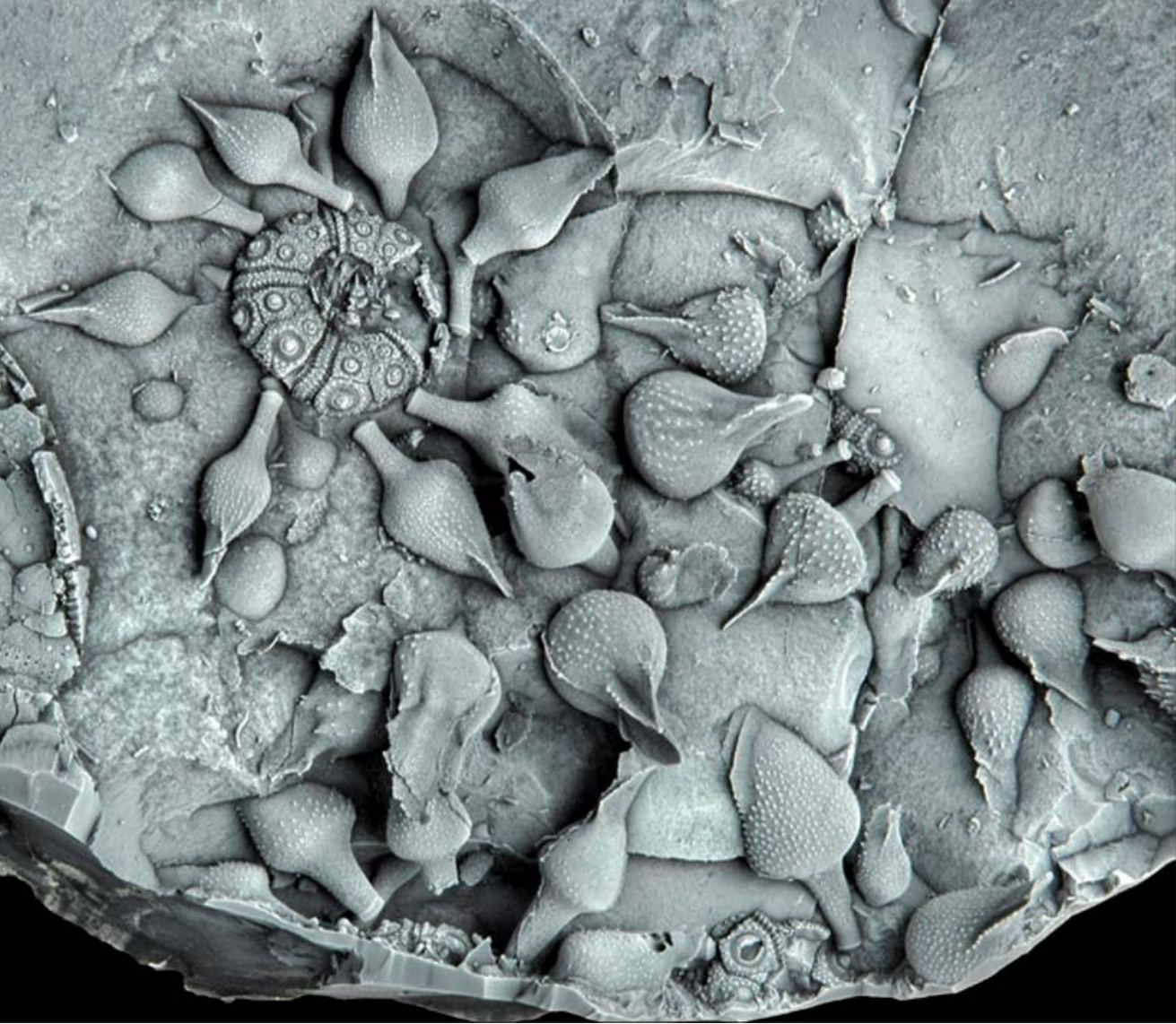

DK 477. Gummiaftryk efter udsyret fossil i flintsten. Tylocidaris vexillifera, skal og tilhørende kølleformede pigge. Sen Danien. Løsblok, Djursland. (Foto: Sten L. Jakobsen, Geologisk Museum, Kbh.) så man får en viden om, "hvad der hører til hvad” og eventuelt også kan få indsigt i en variation fra top til bund både på det enkelte dyr og mellem forskellige individer af samme art.

Endelig kan fund omfatte sammenhob- ninger af mange eksemplarer på et enkelt område, hvilket giver mulighed for at tolke leveforhold og de "katastrofer" som fx undersøiske skred, der både slog dyrene ihjel og også bevarede dem for eftertiden.

Indtil dato er der blevet anerkendt 15 sø- pindsvine-danekræ, mens nogle få er blevet afvist. Blandt de femten erklærede kræ er der eksempler på alle de forskellige grunde til ny viden, som blev nævnt ovenfor. Det allerførste søpindsvine-danekræ (DK 3, danekræ nr. 3) var fx en plade fyldt med omkring 25 skaller af Temnocidaris danica, derudover mængdevis af pigge og tandapparater, som stadigvæk lå på plads i dyrenes mundåbning. Denne ophobning af dyr i en kalkplade fra Fakse Kalkbrud (Mellem Danien) skyldtes helt sikkert et undersøisk skred, som dels transporterede dyrene, dels skilte mange af piggene fra skallerne undervejs og endelig begravede det hele så tilpas dybt, at dyrene ikke var i stand til at presse sig fri igen.

Stereocidaris rosenkrantzi er anden slægt og art af cidaride-gruppen. Dette danekræ (DK 209) er fundet som aftryk i en løs flintblok fra en mark nær Hadsten. Der er skaller af to eksemplarer og pigge, som hører til den ene af disse skaller.

Gennem mange år kendte man kun brudstykker af pigge til en art, der var blevet kaldt Palaeodiadema multiforme. Piggene lignede små padderok-stængler, og som disse var de hule og med piggene etageformet inddelt. Der blev i 1970'erne fundet pladestykker, som formodentlig hørte til sådanne pigge, men det var først med fundet af aftryk i en løsblok (DK 456) ved Røsnæs, at man fik det endelige bevis for samhørigheden mellem pigge og skal. Ydermere fik man en god fornemmelse af, hvor ekstremt lange de tynde pigge var. Nu er navnet revideret til Centrostephanus multiforme.

Søpindsvin med piggene "på plads” i nærheden af skallen omfatter adskillige af danekræene. Disse hører også til de mest spektakulære søpindsvin, fx DK 477, som er en Tylocidaris vexillifera fra en Sen Danien flintblok. Dette søpindsvin havde sære, kølleformede pigge. Nære slægtninge, fx Tylocidaris abildgaardi (DK 202) havde pigge med andre opsvulmede faconer.

Phymosoma granulosum (DK 154) havde lange, glatte pigge. Den levede på skrivekridthavets bløde bund (Sen Maastrichtien, Kridt), og piggene har formodentlig fungeret ligesom "snesko" for at give en større støtteflade for at undgå at synke ned i bunden.

Det nedgravede søpindsvin, Isomicraster sp. (DK 11) stammer fra grønsandet ved Bavnodde på Bornholm (Santonien, Kridt). Tynde, korte, håragtige pigge har siddet på de små knopper på overfladen. Nær bunden sad der stadigvæk små, skovllignende pigge, som var med til at grave og skubbe dyret frem nede i havbunden. Denne slægt søpindsvin kendtes ikke i forvejen fra de bornholmske lag.

Galeaster carinatus er anden gravende form. Dette danekræ (DK 480) er fundet i Klim Kalkgrav (Tidlig Danien). Arten kendtes siden 1927 kun fra det ene eksemplar, der oprindelig lå til grund for opstilling af 
arten, og tilmed var det kendte eksemplar ikke fuldstændigt. Det var imidlertid det nye fund, så nu kunne man se den rigtige facon, og man kunne se gattet samt de forskelligartede pigvorter på ydersiden af skallen.

Andre gravende søpindsvin, som er "nye" i de danske lag omfatter nogle fra lag, som er yngre end kridt- og kalklagene. De er alle fra den gruppe, som populært kaldes “sømus” (i nutiden, bl.a. i Nordsøen, lever søpindsvin med en pigbeklædning, der er helt pelsagtig, deraf navnet). Fra lagene afsat i Sen Oligocæn ved Horsens Fjord er der to fund, der er endt som danekræ, Lovenia hoffmanni (DK 183) og Opissaster? sp. (DK 184). Begge har levet nedgravet i datidens slammede lerbund.

Fra lag af nogenlunde samme geologiske alder er der ved Skyum Bjerge i Thy fundet et meget velbevaret eksemplar af et gravende søpindsvin (DK 238). Sågar pigge er bevaret i furerne på dyrets overside. Denne Proraster eller Schizaster kan vel have dyrket mikroorganismer som føde nede i sin gravegang, i stil med nutidens beslægtede former.

De senest tilkomne danekræ er begge repræsentanter for den kendte slægt, Echinocorys, som blev nævnt som Danmarks almindeligste fossil. Det, som gør fundene til danekræ, er imidlertid, at det ene er fundet i bundlagene (konglomerat) i Arnagerkalken og således repræsenterer tidligere lag, som nu er eroderet bort og kun har efterladt sig rullesten, som indgår i bundlaget. En af disse "rullesten” er et søpindsvin (DK 548). Dels er det det tidligste søpindsvin kendt fra disse lag i Danmark, og dels er det sandsynligvis den tidligste art af Echinocorys, E. gravesi, som gav ophav til den senere mangfoldige udvikling af disse karakteristiske arter for lagene fra de nordlige breddegrader (selvom området lå noget sydligere på kloden dengang).

Indtil videre er rækken af søpindsvinedanekræ sluttet med nr. DK 562, som er en masseophobning af ca. 30 skaller af en Echinocorys. Stykket stammer fra et af de store skred på Møns Klint i de senere år. Finderen, Jytte Frederiksen i Risskov skriver:

"Efter det store skred ved Møns Klint $i$ januar 2007 besøgte vi et par gange den nye kridthalvø med de mange fossiler og de store bøgetrceer, som om sommeren havde kraft nok til at springe ud. Også de nedfaldne frø spirede i kalken. Det var et mageløst sted. På en af turene havde vi det "uheld" at falde over en stor flinteblok med rigtig mange Echinocorys søpindsvin. Det lykkedes ved falles hjcelp at få den store blok op gennem Jydelejet, og da den i efteråret kom til Geologisk Museum, tog Sten Lennart Jakobsen den under kyndig behandling...

Også dette danekrce representerer det frugtbare samspil mellem en glad finder og hjcelpsomme og oplysende professionelle. Vi har lert nyt om søpindsvin og om prcepa-

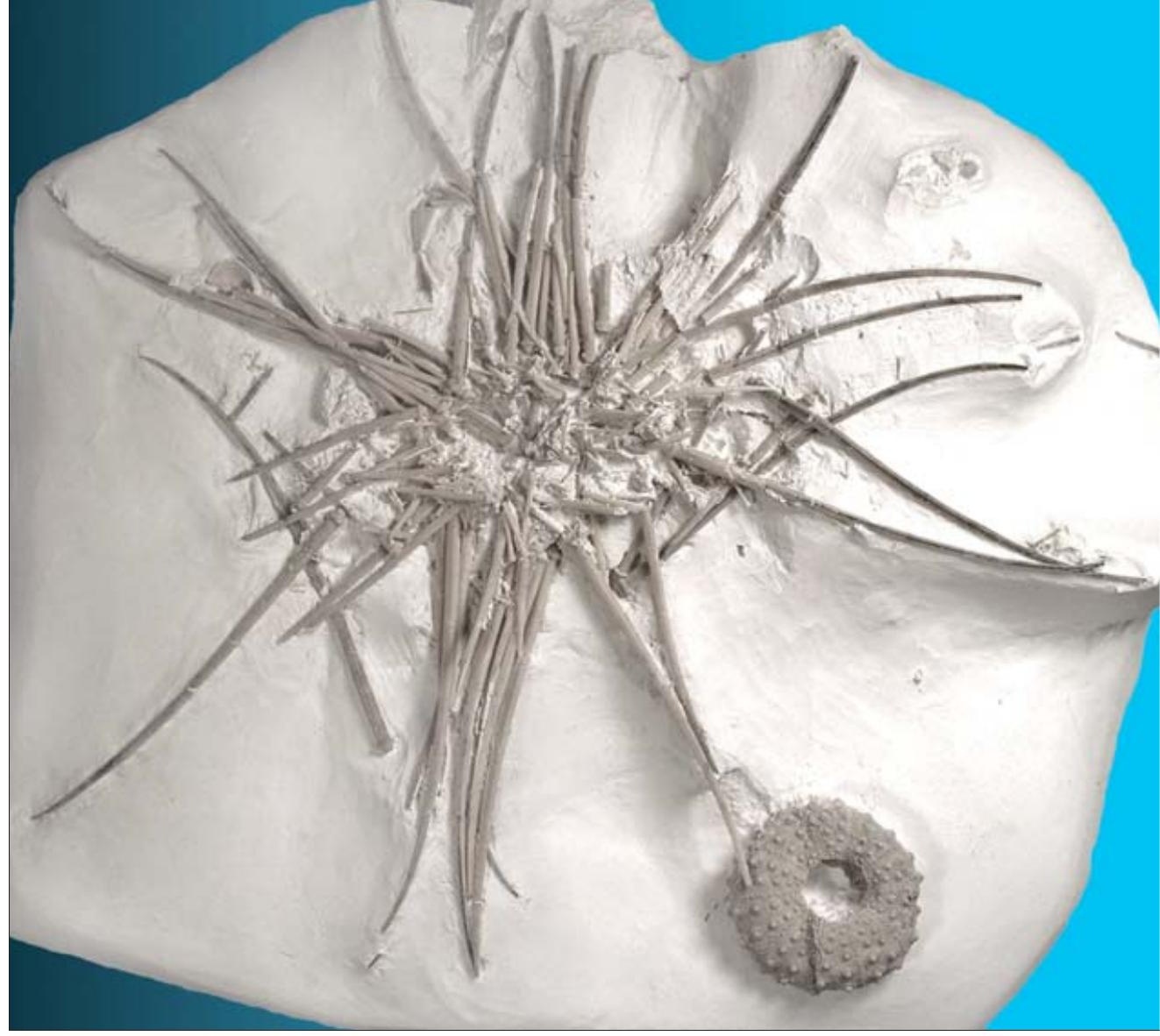

DK 154. Phymosoma granulosum. Pigge og en skal, som er flyttet en smule. Sen Kridt. Skrivekridt, Stevns Klint. (Foto: Sten L. Jakobsen, Geologisk Museum, Kbh.)

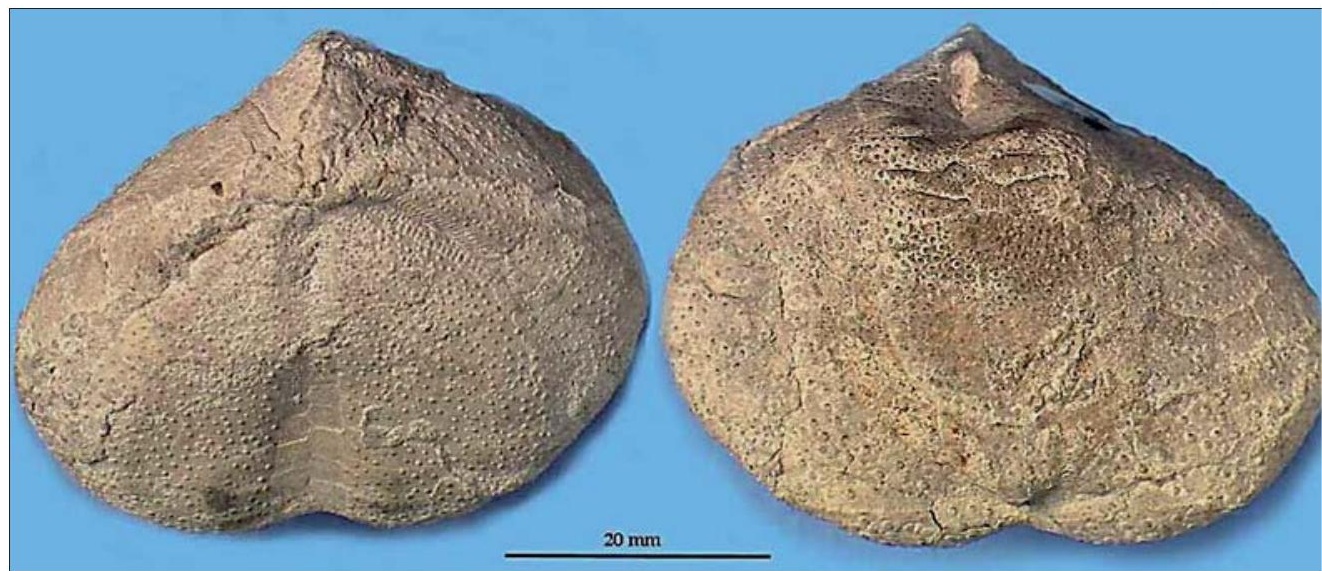

DK 11. Gravende søpindsvin, Isomicraster sp. Santonien, Kridt. Bavnoddegrønsand, Bornholm. (Foto: Sten L. Jakobsen, Geologisk Museum, Kbh.)

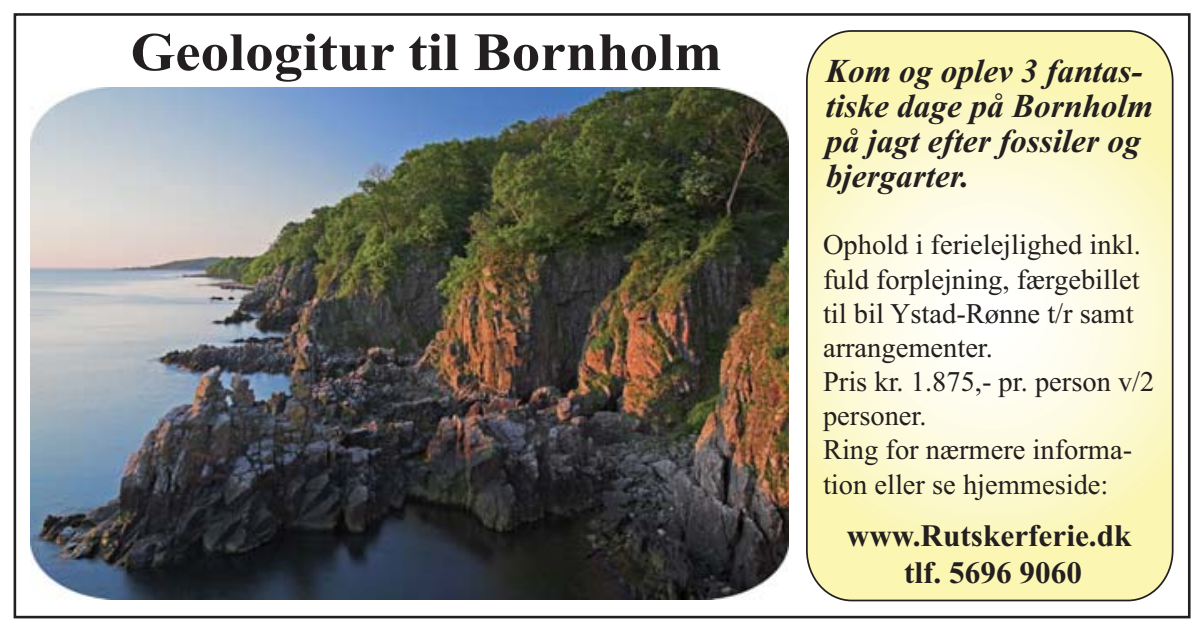


DK 183. En gravende, "sømuslignende” form, Lovenia hoffmanni. Sen Oligoccen. Brejningler, Snaptun ved Horsens Fjord. (Foto: Sten L. Jakobsen, Geologisk Museum, Kbh.)
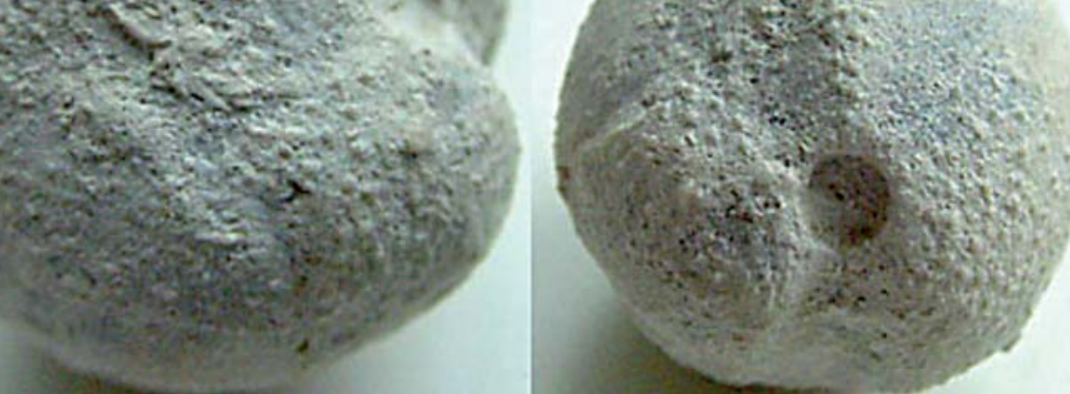

DK 480. Galeaster carinatus. En gravende form set fra forskellige sider. Tidlig Danien. Bryozokalk, Klim Kalkbrud. (Foto: Søren Bo Andersen, Geologisk Institut, Aarhus Universitet)

rering af gode fund. Det har veret sjovt at vare med til".

\section{Søpindsvine-danekræ på nettet}

På forfatterens hjemmeside med søpindsvin
(www.geolsba.dk/echinoids/listeDKkrae. $\boldsymbol{h} \boldsymbol{t m l}$ ) kan man finde en oversigt over søpindsvine-danekræ med større fotos og flere detaljer. Oplysningerne er bragt med tilladelse fra Sten L. Jakobsen på Geologisk
Museum i København. Han står også for langt de fleste fotos i denne oversigt, stor tak for det. Både søpindsvine-danekræ og de øvrige danekræ kan beses på www.danicafossils.dk, klik derefter på DANEKRÆ.

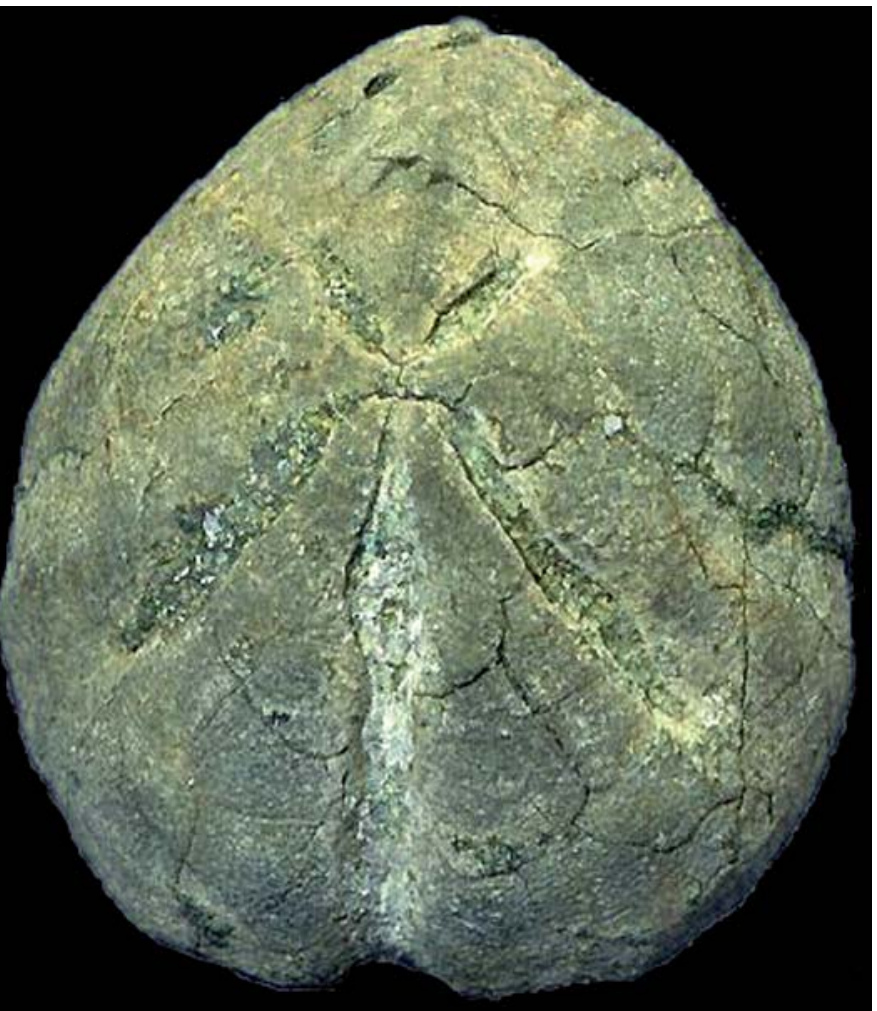

DK 184. En anden gravende, "sømuslignende" form, Opissaster? sp. Sen Oligoccen. Brejningler, Snaptun ved Horsens Fjord. (Foto: Sten L. Jakobsen, Geologisk Museum, Kbh.)

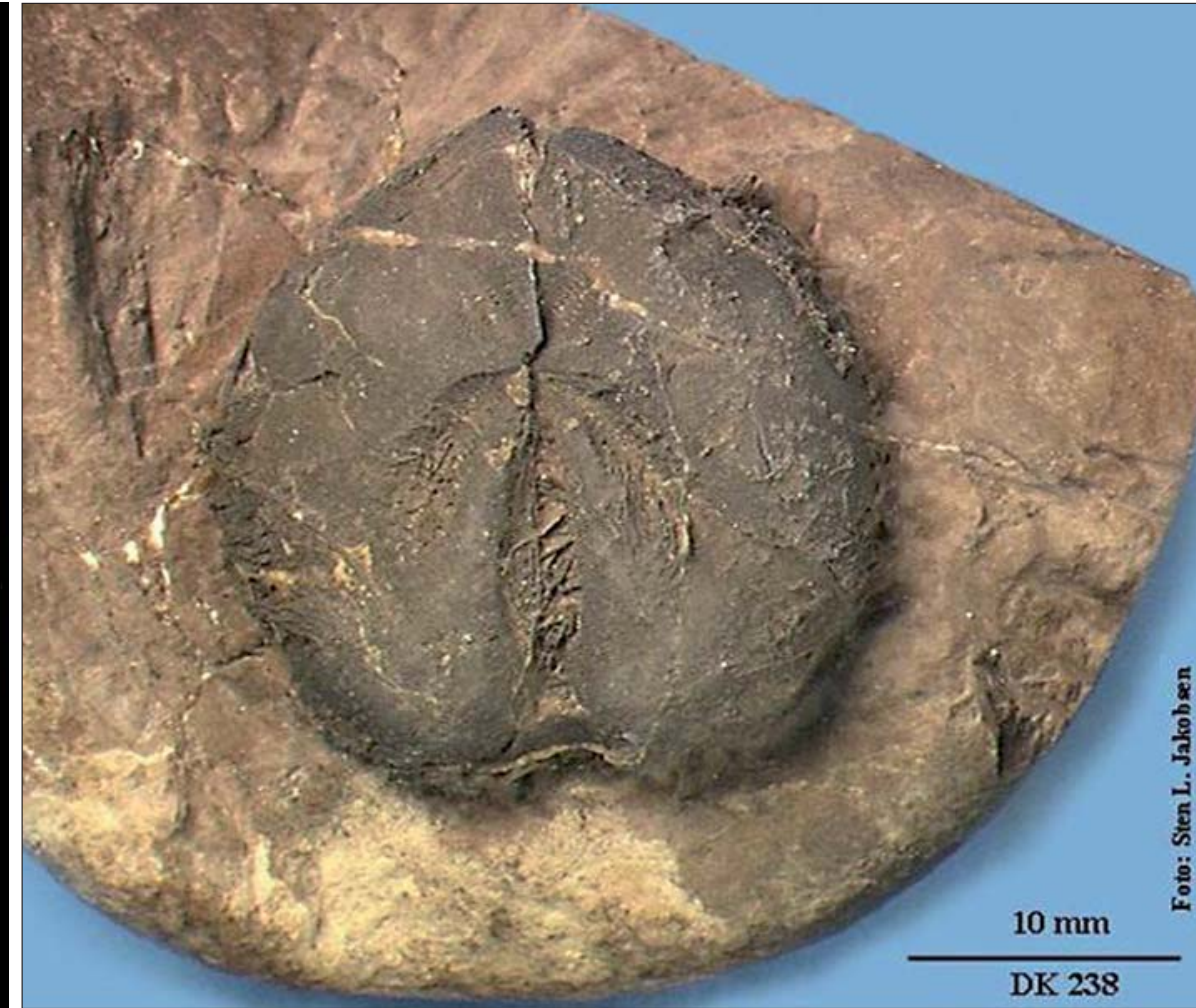

DK 238. Proraster eller Schizaster. Skal med pigge bevaret i oversidens furer. Sen Oligoccen eller Tidlig Mioccen. Løsblok, Skyum Bjerge, Thy. (Foto: Sten L. Jakobsen, Geologisk Museum, Kbh.) 
DK 548. Blok af

Arnagerkalkens

bundkonglomerat

med sorte og grønne rullesten af tidligere, nu borteroderede lag. Heriblandt et søpindsvin, Echinocorys gravesi? Turonien?-Cenomanien. Arnager Klint, Bornholm. (Foto: Sten L. Jakobsen, Geologisk Museum, Kbh.)

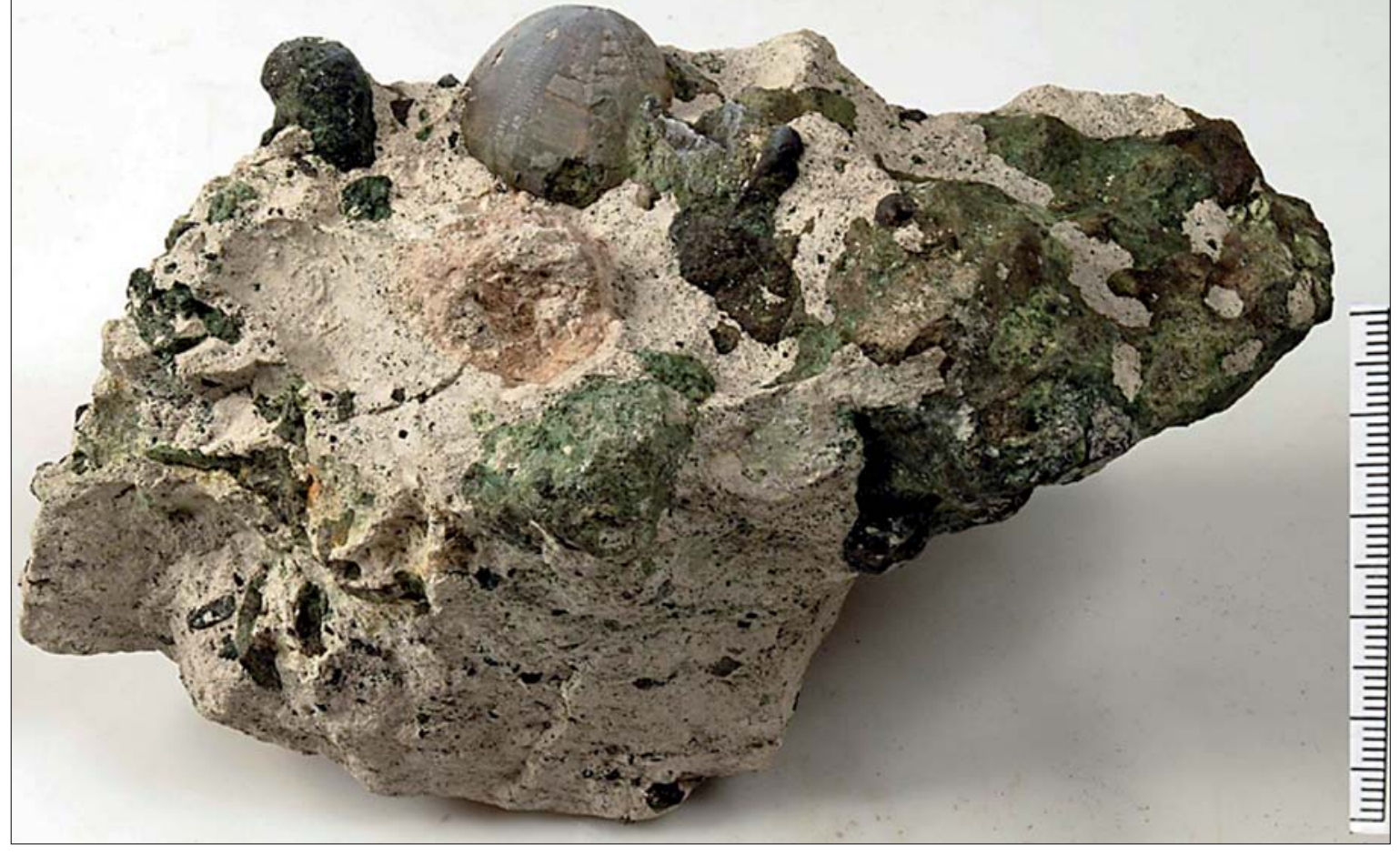

På Geologisk Museums nyhedsside kan DK 548 ses her:

http://geologi.snm.ku.dk/nyheder_gm/ nyhed160109/

\section{Las mere og se flere fotos på forfatterens hjemmeside:} www.geolsba.dk/echinoids/listeDKkrae.html

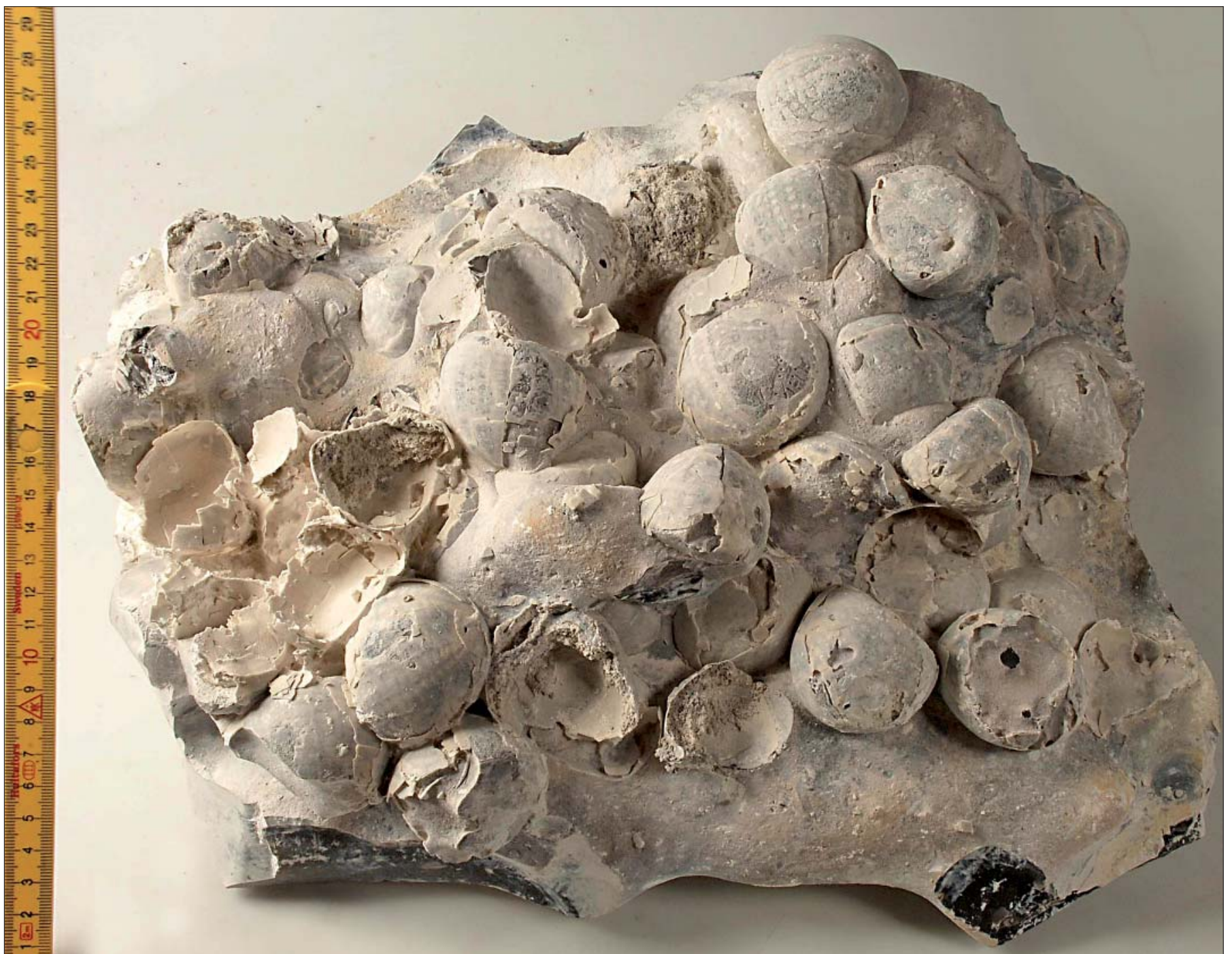

DK 562. Masseforekomst af Echinocorys sp. Skred i skrivekridt. Tidlig Maastrichtien, Kridt. Møns Klint. (Foto: Sten L. Jakobsen, Geologisk Museum, Kbh.) 